\title{
Collagen-binding activity of Prevotella intermedia measured by a microtitre plate adherence assay
}

\author{
Daniel Grenier \\ Tel: +14186567341. Fax: +1 4186562861 . \\ e-mail: Daniel.Grenier@greb.ulaval.ca
}

Groupe de Recherche en Ecologie Buccale, Faculté de Médecine Dentaire, Université Laval, SainteFoy, Québec, Canada G1K 7P4

\begin{abstract}
The ability of Prevotella intermedia to bind type I collagen was investigated. A simple method in which bacterial cells were allowed to attach to collagencoated microtitre plate wells was used to characterize the activity. All strains of $\boldsymbol{P}$. intermedia tested, as well as those of the closely related species Prevotella nigrescens, showed a capacity to attach to the collagen film. Exponential-phase cultures of $P$. intermedia demonstrated a greater binding capacity than older cells. Attachment to the collagen film was inhibited by the presence of EDTA, type I and IV collagen, denatured collagen (gelatin), fibrinogen or fibronectin. Pretreatment of bacterial cells with heat $\left(60^{\circ} \mathrm{C}\right.$, $\mathbf{3 0} \mathrm{min}$ ) or proteinase $\mathrm{K}$ also inhibited the binding. The collagen-binding activity could be solubilized from the bacterial cell surface by incubation with Zwittergent 3-14, a zwitterionic detergent. The collagen-binding capacity of $P$. intermedia demonstrated in the present study represents a mechanism of colonization allowing these bacteria to attach to a tissue matrix.
\end{abstract}

Keywords: Prevotella, periodontopathogen, periodontal disease, collagen-binding activity, bacterial adherence

\section{INTRODUCTION}

Prevotella intermedia and Prevotella nigrescens, both formerly designated $P$. intermedia (Shah \& Gharbia, 1992), may be isolated from subgingival sites of healthy patients and of those suffering from various forms of periodontal diseases (Slots \& Listgarten, 1988; Teanpaisan et al., 1995), which suggests that they may be opportunistic pathogens. Virulence factors that may be important for the virulence of these bacteria include hydrolytic enzymes and hostbinding activities (Holt \& Bramanti, 1991).

The ability of periodontopathogens to attach to oral surfaces is believed to be a critical step in the initiation of the pathogenic process of periodontal diseases. Previous reports have shown that $P$. intermedia can attach to epithelial cells, erythrocytes and other oral bacteria (Devine \& Handley, 1989; Leung et al., 1989). Host proteins, including fibrinogen, laminin and $\mathrm{IgG}$, are also bound by $P$. intermedia (Kalfas et al., 1992; Labbé \& Grenier, 1995; Lantz et al., 1985). In the present investigation, the ability of $P$. intermedia to bind collagen was demonstrated and characterized using a simple microtitre plate adherence assay.

\section{METHODS}

Bacteria and growth conditions. $P$. intermedia strain $\mathrm{BMH}$, obtained from B. C. McBride (University of British Columbia, Vancouver, Canada), was used in most experiments. This isolate was identified in a previous study (Jansen et al., 1995) using the Rapid ID 32A system (Bio-Mérieux) and multilocus enzyme electrophoresis. Other oral bacterial strains, listed in Table 1, were also tested for their collagen-binding activity. Except for Treponema denticola, bacteria were grown anaerobically $\left[\mathrm{N}_{2} / \mathrm{H}_{2} / \mathrm{CO}_{2}(80: 10: 10\right.$, by vol.) $]$ at $37^{\circ} \mathrm{C}$ in brain heart infusion broth (BBL Microbiology Systems) supplemented with haemin $\left(10 \mu \mathrm{g} \mathrm{ml}^{-1}\right)$ and vitamin $\mathrm{K}\left(1 \mu \mathrm{g} \mathrm{ml}^{-1}\right)$. T. denticola was cultivated under the same conditions but in the oral spirochaete medium as previously described by Leschine \& Canale-Parola (1980). Unless indicated, bacteria were grown to early stationary phase (approximately $24 \mathrm{~h}$ ), harvested by centrifugation, washed twice in PBS $(0.145 \mathrm{M} \mathrm{NaCl} ; 0.05 \mathrm{M}$ sodium phosphate), $\mathrm{pH} 7.0$, and suspended in the same buffer to an $\mathrm{OD}_{660}$ of $2 \cdot 0$.

Microtitre plate collagen-binding assay. Type I acid-soluble collagen (calf skin; Sigma) was prepared in $0.02 \%$ acetic acid, to a concentration of $2 \mathrm{mg} \mathrm{ml}^{-1}$, by continuous stirring at $4{ }^{\circ} \mathrm{C}$ for $16 \mathrm{~h}$. Wells of a flat-bottomed microtitre plate (Immulon 1; 
Dynatech Laboratories) were filled with the collagen solution $(100 \mu \mathrm{l})$, and the plate was incubated overnight at room temperature. Control wells were coated with $1 \%(\mathrm{w} / \mathrm{v})$ BSA. The protein solution was removed and $0.05 \%$ glutaraldehyde $(100 \mu \mathrm{l})$ was subsequently added. After $45 \mathrm{~min}$ at room temperature, the glutaraldehyde was removed and the wells were washed twice with distilled water. BSA ( $100 \mu \mathrm{l}$ of a $2 \%$ solution) was then added to the wells to block unoccupied sites and prevent non-specific binding of bacteria. After $30 \mathrm{~min}$ at room temperature, the BSA was removed and the wells were washed once with distilled water. Finally, the bacterial suspension $(100 \mu \mathrm{l})$ was added and the plate was incubated at $37^{\circ} \mathrm{C}$ for $1.5 \mathrm{~h}$ with gentle shaking every $20 \mathrm{~min}$. After the attachment period, unbound bacteria were removed by washing the wells three times with PBS containing $0.01 \%$ Tween 20 to minimize nonspecific hydrophobic interactions. Bacteria left adhering to the wells were fixed with Bouin's fixative (Ivey, 1980) for $10 \mathrm{~min}$. After extensive washing with distilled water, bacteria were stained for $15 \mathrm{~min}$ with Hucker crystal violet (Sonnenwirth, 1980). Wells were then rinsed with distilled water and dried at $37^{\circ} \mathrm{C}$ for $2 \mathrm{~h}$. After adding $200 \mu \mathrm{l} 95 \%$ (v/v) ethanol to each well, the plate was shaken vigorously to release the stain. The $A_{590}$ was then recorded using an Easy Beam microtitre plate reader (SLT-Labinstruments). All assays were performed in triplicate and the means \pm SD were calculated. In one experiment, the number of bound bacteria was estimated by measuring the $A_{590}$ produced by stained bacterial films containing a known quantity of cells. In this case, the concentration of a cell suspension of $P$. intermedia was determined using a PetroffHausser counting chamber according to the manufacturer's instructions. Various dilutions of the suspension were added to the wells of a microtitre plate, the bacteria were dried, fixed and stained, and the $A_{590}$ was measured, as described above.

Effect of pH on collagen-binding activity. The collagenbinding assay was performed using suspensions of $P$. intermedia BMH prepared in the following buffers at $50 \mathrm{mM}$ : citrate buffer ( $\mathrm{pH} 3,4,5)$, phosphate buffer ( $\mathrm{pH} 6,7)$, Tris/ $\mathrm{HCl}$ buffer ( $\mathrm{pH} 8$, $9)$ and carbonate buffer $(\mathrm{pH} \mathrm{10)}$.

Effect of putative inhibitors on collagen-binding activity. Putative inhibitors of bacterial adherence were incorporated in the bacterial suspension, and the collagen-binding assay was carried out as described above. The following compounds were tested: human serum (1:10 dilution in PBS); stimulated whole human saliva (1:10 dilution in PBS); $50 \mathrm{mM}$ EDTA; various carbohydrates at $100 \mathrm{mM}$ (galactose, glucose, $N$-acetyl-Dgalactosamine, $N$-acetyl-D-glucosamine); various proteins at $0 \cdot 1 \%$ (BSA, gelatin, IgG, fibrinogen, fibronectin, type I acidsoluble collagen, type IV acid-soluble collagen); various amino acid and synthetic peptides at $0.1 \%$ [glycine, proline, polyglycine (molecular mass $=2-5 \mathrm{kDa}$ ), polyproline (molecular mass $=1-10 \mathrm{kDa}$ ), poly(Pro-Gly-Pro) (molecular mass $=$ 2-10 kDa), Cys-Gln-Asp-Ser-Glu-Thr-Arg-Thr-Phe-Tyr (a fibronectin-related peptide)].

Effect of treatments on collagen-binding activity. Bacterial cells were incubated at $4{ }^{\circ} \mathrm{C}(1$ month $), 37^{\circ} \mathrm{C}(2 \mathrm{~d}), 50^{\circ} \mathrm{C}$ $(30 \mathrm{~min})$ or $60^{\circ} \mathrm{C}(30 \mathrm{~min})$ before the collagen-binding activity was assayed. The bacterial cells were also submitted to a light ultrasonic treatment in order to detach any loosely bound structures or proteins. In this case, the bacterial suspension was sonicated $(3 \times 10 \mathrm{~s}, 20 \%$ duty cycle; Sonic dismembrator model 150, Artek Systems) and the cells were washed twice by centrifugation before measuring collagen-binding activity. $\mathrm{pH}$ stability of the binding activity was tested by incubating bacteria at room temperature for $60 \mathrm{~min}$ at either $\mathrm{pH} 2$ or $\mathrm{pH} 12$. The sensitivity of the collagen-binding activity to proteolytic enzymes was evaluated by incubating bacteria at $37^{\circ} \mathrm{C}$ for $2 \mathrm{~h}$ in the presence of either trypsin or proteinase $\mathrm{K}\left(1 \mathrm{mg} \mathrm{ml}^{-1}\right)$. The bacterial cells were also treated at room temperature for $1 \mathrm{~h}$ with constant agitation in the presence of $100 \mathrm{mM}$ EDTA, $400 \mathrm{mM}$ sodium chloride, $100 \mathrm{mM}$ sodium periodate, $0.01 \%$ ([3-cholamidopropyl]dimethylammonio)-1-propanesulfonate (CHAPS), $\quad 0.01 \%$ hexadecyltrimethylammonium bromide (HTAB), $0.01 \%$ SDS, $0.01 \%$ Triton X-100, 0.01\% Tween 20 or $0.01 \%$ Zwittergent 3-14. All the above-treated bacteria were washed twice and suspended $\left(\mathrm{OD}_{660}=2 \cdot 0\right)$ in PBS before the collagen-binding activity was assayed.

\section{RESULTS}

All nine strains of $P$. intermedia/ $P$. nigrescens tested in the study attached to various extents to type I collagen (calf skin) immobilized onto wells of a microtitre plate (Table 1). No attachment occurred when wells were coated with BSA. Coating the wells with type I human collagen resulted in an attachment comparable to that of type I calfskin collagen (data not shown). Among the other bacterial species tested, only Porpbyromonas gingivalis ATCC 33277 and Eubacterium saburreum 162.4 bound significantly to the collagen-coated wells (Table 1). In the former case, the adherence did not appear to be specific since bacteria also attached to the same extent to the control well covered with BSA. A second strain of Por. gingivalis (W83) did not bind to the collagen film. P. intermedia strain $\mathrm{BMH}$ was selected for further characterization of the collagenbinding activity.

Table 1. Ability of selected oral bacteria to attach to collagen immobilized onto wells of a microtitre plate

Adherence is measured as the $A_{590}$ value.

Strain

Adherence

(mean \pm SD)

Prevotella intermedia $\mathrm{BMH}$

Prevotella intermedia $\mathrm{BH} 20 / 30$

Prevotella intermedia MS/5B/372

$0.67 \pm 0.08$

Prevotella intermedia G8-9K-3

Prevotella nigrescens $\mathrm{T} 2$

Prevotella nigrescens $\mathrm{S} 19 \mathrm{~g}$

Prevotella nigrescens NCTC 9336

Prevotella nigrescens $\mathrm{Cg} 1265$

Prevotella nigrescens 5W2

Prevotella loescheii ATCC 15930

Porphyromonas gingivalis ATCC 33277

Porphyromonas gingivalis W83

Treponema denticola ATCC 35405

Actinobacillus actinomycetemcomitans 702

Eubacterium saburreum 162.4

Actinomyces viscosus 54.2

Actinomyces naeslundii 85.1

Streptococcus mutans ATCC 10449
$0 \cdot 52 \pm 0 \cdot 10$

$0.32 \pm 0.09$

$0 \cdot 87 \pm 0 \cdot 13$

$0.68 \pm 0.11$

$0 \cdot 40 \pm 0.07$

$0 \cdot 30 \pm 0.08$

$0 \cdot 23 \pm 0 \cdot 10$

$0 \cdot 37 \pm 0.05$

0

$0 \cdot 81 \pm 0 \cdot 14$

$0 \cdot 09 \pm 0 \cdot 05$

0

0

$0 \cdot 17 \pm 0 \cdot 08$

0

0

0 
Table 2. Effect of various putative inhibitors on adherence of $P$. intermedia BMH to collagen immobilized onto wells of a microtitre plate

\begin{tabular}{llc|}
\hline Compound & Concentration* & $\begin{array}{c}\text { Percentage } \\
\text { adherence } \\
\text { (mean } \pm \text { SD) }\end{array}$ \\
\hline None (control) & & 100 \\
EDTA & $50 \mathrm{mM}$ & $25 \pm 11$ \\
Serum & Dilution $1: 10$ & 0 \\
Saliva & Dilution $1: 10$ & $19 \pm 9$ \\
BSA & $0 \cdot 2 \%$ & $104 \pm 15$ \\
Gelatin & $0 \cdot 2 \%$ & $7 \pm 6$ \\
Type I acid-soluble collagen & $0 \cdot 05 \%$ & $12 \pm 7$ \\
Type IV acid-soluble collagen & $0 \cdot 05 \%$ & $12 \pm 5$ \\
Fibrinogen & $0 \cdot 2 \%$ & $29 \pm 13$ \\
Fibronectin & $0 \cdot 025 \%$ & $15 \pm 5$ \\
IgG & $0 \cdot 2 \%$ & $97 \pm 10$ \\
Galactose & $100 \mathrm{mM}$ & $97 \pm 7$ \\
$N$-Acetyl-D-galactosamine & $100 \mathrm{mM}$ & $101 \pm 7$ \\
Glucose & $100 \mathrm{mM}$ & $109 \pm 15$ \\
$N$-Acetyl-D-glucosamine & $100 \mathrm{mM}$ & $104 \pm 9$ \\
Glycine & $0 \cdot 2 \%$ & $103 \pm 12$ \\
Proline & $0 \cdot 2 \%$ & $112 \pm 17$ \\
Polyglycine & $0 \cdot 2 \%$ & $99 \pm 6$ \\
Poly-L-proline & $0 \cdot 2 \%$ & $95 \pm 7$ \\
Poly(Pro-Gly-Pro) & $0 \cdot 2 \%$ & $93 \pm 10$ \\
Cys-Gln-Asp-Ser-Glu-Thr-Arg-Thr-Phe-Tyr & $0 \cdot 2 \%$ & $90 \pm 12$ \\
\hline
\end{tabular}

* Final concentration in the assay.

Preliminary experiments showed that the adherence of $P$. intermedia $\mathrm{BMH}$ to the collagen film was time- and bacterial-concentration-dependent (data not shown). The adherence assay was found to be reproducible; triplicate experiments gave $A_{590}$ values ranging from 0.62 to 0.76 $(0.67 \pm 0.08)$. Using bacterial suspensions with known concentrations, it was estimated that in the assay performed, the number of cells attached to the collagen film was approximately $2 \times 10^{7}$ per well. Mid-exponentialphase cultures of $P$. intermedia demonstrated the greatest capacity to bind to the collagen film $\left(A_{590}=0.85 \pm 0.1\right)$. A significant decrease in attachment was observed with cells from a 6-d-old culture $\left(A_{590}=0 \cdot 32 \pm 0 \cdot 07\right)$. Optimal attachment occurred between $\mathrm{pH} 7$ and $\mathrm{pH} 8$, whereas no binding was observed when the assay was carried out at $\mathrm{pH} 3$ or $\mathrm{pH} 10$.

Table 2 presents data concerning the effect of various putative inhibitors on the adherence of $P$. intermedia to collagen-coated wells. Incorporation of the chelating agent EDTA in the bacterial suspension was associated with a $75 \%$ reduction of bacterial attachment. Among the proteins tested, gelatin, type I and type IV collagens, fibrinogen, as well as fibronectin, reduced the attachment of $P$. intermedia. Human serum and saliva also interfered with the adherence, whereas no effect was observed with BSA and IgG. Carbohydrates, amino acids and peptides tested had no inhibitory effect. Synthetic peptides with a high content in glycine and proline (as for collagen), as well as a fibronectin-related peptide, did not interfere with the binding.

The effect of various cell treatments on the collagenbinding activity of $P$. intermedia is reported in Table 3 . The collagen-binding activity was not eliminated by a light ultrasonic treatment. The bacteria could be stored for up to one month at $4{ }^{\circ} \mathrm{C}$ or for $2 \mathrm{~d}$ at $37^{\circ} \mathrm{C}$ with no apparent loss of binding activity. Collagen-binding activity was extinguished by treatment of the bacteria at $60^{\circ} \mathrm{C}$ for $30 \mathrm{~min}$, at $\mathrm{pH} 2$ or 12 , as well as by incubation in the presence of proteinase $\mathrm{K}$ or sodium periodate. The collagen-binding activity was not affected by treatment with trypsin. Among the various detergents used, Zwittergent 3-14 was the only one to have a significant effect; after treating cells with it, collagen-binding activity could not be demonstrated. Incorporating the resulting detergent fraction during the adherence assay could also prevent the binding of untreated cells (data not shown). No such inhibition was demonstrated with the other detergents used in the investigation.

\section{DISCUSSION}

The microtitre plate adherence assay used in this study was found to be convenient. It gives an excellent reproducibility, is easy to perform and does not require sophisticated equipment. Furthermore, a number of cell 
Table 3. Effect of various treatments of $P$. intermedia $\mathrm{BMH}$ on adherence to collagen immobilized onto wells of a microtitre plate

\begin{tabular}{|c|c|}
\hline Treatment & $\begin{array}{l}\text { Percentage } \\
\text { adherence } \\
\text { (mean } \pm \mathrm{SD})\end{array}$ \\
\hline None & 100 \\
\hline Light sonication & $104 \pm 10$ \\
\hline \multicolumn{2}{|l|}{ Storage } \\
\hline $37^{\circ} \mathrm{C} / 2 \mathrm{~d}$ & $92 \pm 12$ \\
\hline $4{ }^{\circ} \mathrm{C} / 1$ month & $99 \pm 8$ \\
\hline \multicolumn{2}{|l|}{ Heat } \\
\hline $50{ }^{\circ} \mathrm{C} / 30 \mathrm{~min}$ & $95 \pm 11$ \\
\hline $60^{\circ} \mathrm{C} / 30 \mathrm{~min}$ & $12 \pm 4$ \\
\hline \multicolumn{2}{|l|}{$\mathrm{pH}^{*}$} \\
\hline 2 & $4 \pm 3$ \\
\hline 12 & $7 \pm 13$ \\
\hline \multicolumn{2}{|l|}{ Proteolytic enzymes $†$} \\
\hline Trypsin $\left(1 \mathrm{mg} \mathrm{m}^{-1}\right) \ddagger$ & $96 \pm 9$ \\
\hline Proteinase $\mathrm{K}\left(1 \mathrm{mg} \mathrm{ml}^{-1}\right) \ddagger$ & $5 \pm 6$ \\
\hline \multicolumn{2}{|l|}{ Chemicals* } \\
\hline EDTA $(100 \mathrm{mM}) \ddagger$ & $80 \pm 16$ \\
\hline $\mathrm{NaCl}(400 \mathrm{mM}) \ddagger$ & $95 \pm 6$ \\
\hline Sodium periodate $(0 \cdot 1 \mathrm{M}) \ddagger$ & $3 \pm 4$ \\
\hline \multicolumn{2}{|l|}{ Detergents* } \\
\hline CHAPS $(0.01 \%) \ddagger$ & $95 \pm 7$ \\
\hline $\operatorname{HTAB}(0.01 \%) \ddagger$ & $83 \pm 11$ \\
\hline $\operatorname{SDS}(0.01 \%) \ddagger$ & $80 \pm 14$ \\
\hline Triton X-100 $(0.01 \%) \ddagger$ & $76 \pm 12$ \\
\hline Tween $20(0 \cdot 01 \%) \ddagger$ & $97 \pm 8$ \\
\hline Zwittergent 3-14 $(0.01 \%) \ddagger$ & $4 \pm 6$ \\
\hline
\end{tabular}

$* 25{ }^{\circ} \mathrm{C}$ for $1 \mathrm{~h}$.

$+37^{\circ} \mathrm{C}$ for $2 \mathrm{~h}$.

$\ddagger$ Final concentration during treatment.

treatments and putative inhibitors of adherence can be tested in a short period of time to characterize the nature of the binding component.

The data presented in this report suggest a specific interaction between $P$. intermedia and type I collagen. Non-specific binding of $P$. intermedia to collagen must be ruled out because (i) no attachment of bacteria to BSAcoated wells was detected and (ii) complete inhibition of attachment occurred in the presence of free soluble collagen or its denatured form (gelatin). Collagen-binding capacity has been previously demonstrated for other oral bacterial species, including certain streptococci of the mutans group (Liu \& Gibbons, 1990), Actinomyces viscosus (Liu et al., 1991) and Por. gingivalis (Naito \& Gibbons, 1988). The collagen-binding activity of the mutans streptococci is heat-sensitive and not affected by carbohydrates, fibrinogen and fibronectin (Liu \& Gibbons, 1990). A. viscosus attaches to human type I collagen but not to its denatured form or to type I rat collagen. It has been suggested that this binding to collagen is associated with type 1 fimbriae rather than type 2 fimbriae (Liu et al., 1991). The collagen-binding activity of Por. gingivalis is heat-sensitive and inhibited by human serum, $\operatorname{IgG}$, fibrinogen and fibronectin (Naito \& Gibbons, 1988).

The fact that incorporation, in the adherence assay, of fibronectin, a collagen-binding glycoprotein, prevents the attachment of $P$. intermedia suggests that the same binding site on the collagen molecule may be involved in the binding of fibronectin and bacteria. This is reinforced by the fact that preincubation of bacteria with fibronectin did not reduce their ability to adhere to collagen and that fibronectin-coated wells did not allow attachment of $P$. intermedia (data not shown).

On the basis of heat sensitivity and susceptibility to proteinase $\mathrm{K}$, the receptor for collagen on $P$. intermedia may contain a proteinaceous moiety. Furthermore, the inhibition obtained by treating cells with sodium periodate suggests that the binding component may be a glycoconjugate. Devine \& Handley (1989) have reported that a proteinase-K-sensitive, trypsin-resistant component on fibrils of $P$. intermedia is involved in the coaggregation reaction of the bacteria with Actinomyces spp. Based on these characteristics, the same receptor may be involved in the attachment of $P$. intermedia to Actinomyces spp. and to collagen.

The plasma protein fibrinogen could also prevent the attachment of $P$. intermedia to collagen-coated wells. Binding of fibrinogen by $P$. intermedia has been previously reported by Lantz et al. (1985). It was shown that this heat-sensitive adherence mechanism is not affected by the presence of EDTA. On the contrary, the collagen-binding activity reported in the present study was strongly inhibited by the chelating agent. It is possible then that inhibition by fibrinogen is related to steric hindrance, due to the close proximity of both receptors, rather than to a direct competition for the same binding component. One should not rule out the possibility that some fibronectin contamination present in the commercial fibrinogen preparation may be responsible for the inhibition. The finding with respect to the Zwittergent 3-14 extraction of the collagen-binding component may be used to develop a strategy for the purification of the putative ligand.

The present investigation reports for the first time the ability of $P$. intermedia to bind collagen. Since the major constituent of periodontal tissues is collagen, primarily type I in the tissue and type IV in the basement membrane (Narayanan \& Page, 1983), it is suggested that the collagen-binding capacity of $P$. intermedia may play a key role in tissue invasiveness and colonization by providing a mechanism allowing the cells to attach to a tissue matrix.

\section{ACKNOWLEDGEMENTS}

This work was supported by the Medical Research Council of Canada. 


\section{REFERENCES}

Devine, D. A. \& Handley, P. S. (1989). The relationship between coaggregation properties and surface structures of Bacteroides intermedius. Microb Ecol Health Dis 2, 267-278.

Holt, S. C. \& Bramanti, T. E. (1991). Factors in virulence expression and their role in periodontal disease pathogenesis. Crit Rev Oral Biol Med 2, 177-281.

Ivey, M. H. (1980). Laboratory procedures in parasitology. In Gradwobls Clinical Laboratory Methods and Diagnosis, 8th edn, p. 2194. Edited by A. C. Sonnenwirth \& L. Jarett. St Louis: The C. V. Mosby Company.

Jansen, H.-J., Grenier, D. \& Van der Hoeven, J. S. (1995). Characterization of immunoglobulin G-degrading proteases of Prevotella intermedia and Prevotella nigrescens. Oral Microbiol Immunol 10, 138-145.

Kalfas, S., Tigyi, Z., Wikström, M. \& Naidu, A. S. (1992). Laminin binding to Prevotella intermedia. Oral Microbiol Immunol 7, 235-239.

Labbe, S. \& Grenier, D. (1995). Characterization of the human immunoglobulin G Fc-binding activity of Prevotella intermedia. Infect Immun 63, 2785-2789.

Lantz, M. S., Switalski, L. M., Kornman, K. S. \& Hobk, M. (1985). Bacteroides intermedius binds fibrinogen. $J$ Bacteriol 163, 623-628.

Leschine, S. B. \& Canale-Parola, E. (1980). Rifampin as a selective agent for isolation of oral spirochetes. J Clin Microbiol 12, 792-795.

Leung, K.-P., Fukushima, H., Sagawa, H., Walker, C. B. \& Clark, W. B. (1989). Surface appendages, hemagglutination, and adherence to human epithelial cells of Bacteroides intermedius. Oral Microbiol Immunol 4, 204-210.
Liu, T. \& Gibbons, R. J. (1990). Binding of streptococci of the 'mutans' group to type I collagen associated with apatitic surfaces. Oral Microbiol Immunol 5, 131-136.

Liu, T., Gibbons, R. J., Hay, D. I. \& Skobe, Z. (1991). Binding of Actinomyces viscosus to collagen: association with the type 1 fimbrial adhesin. Oral Microbiol Immunol 6, 1-5.

Naito, Y. \& Gibbons, R. J. (1988). Attachment of Bacteroides gingivalis to collagenous substrata. J Dent Res 67, 1075-1080.

Narayanan, S. N. \& Page, R. (1983). Connective tissues of the periodontium. Collagen Relat Res 3, 33-64.

Shah, H. N. \& Gharbia, S. E. (1992). Biochemical and chemical studies on strains designated Prevotella intermedia and proposal of a new pigmented species, Prevotella nigrescens sp. nov. Int $J$ Syst Bacteriol 42, 542-546.

Slots, J. \& Listgarten, M. A. (1988). Bacteroides gingivalis, Bacteroides intermedius and Actinobacillus actinomycetemcomitans in human periodontal diseases. J Clin Periodontol 15, 85-93.

Sonnenwirth, A. C. (1980). Stains and staining procedures. In Gradwobl's Clinical Laboratory Methods and Diagnosis, 8th edn, p. 1380. Edited by A. C. Sonnenwirth \& L. Jarett. St Louis: The C. V. Mosby Company.

Teanpaisan, R., Douglas, C. W. I. \& Walsh, T. F. (1995). Characterization of black-pigmented anaerobes isolated from diseased and healthy periodontal sites. J Periodontal Res 30, 245-251.

Received 7 November 1995; revised 22 January 1996; accepted 24 January 1996. 